\title{
Alur Perdagangan Hiu sebagai Komoditas Ikan Hias dari Provinsi Bali
}

\author{
Ni Made Putri Handayani ${ }^{\text {* }}$, Pande Gde Sasmita Julyantoro a, I Ketut Wija Negara ${ }^{\text {a }}$ \\ a Program Studi Manajemen Sumberdaya Perairan, Fakultas Kelautan dan Perikanan, Universitas Udayana, Bukit Jimbaran, Kabupaten Badung, \\ Provinsi Bali-Indonesia \\ * Ni Made Putri Handayani. Tel.: +6282146413641 \\ Alamat e-mail: made.putri.handayani@gmail.com
}

Diterima (received) 8 Juni 2017; disetujui (accepted) 24 Agustus 2017; tersedia secara online (available online) 26 Agustus 2017

\begin{abstract}
This study objectives were to investigate the track of shark trade from Bali Province, the exports volume of shark trade during 2015-2016, the length of sharks; species exported in the ETP category; and the effectiveness of shark trade license by BPSPL Denpasar based on EAFM analysis. This study used exploration method with questionnaires, interviews and secondary data from BPSPL Denpasar. The results showed that the track of shark trade started from when the shark is caught by the fishermen which purchased by exporter companies, then they had to get shipment recommendation letter from BPSPL Denpasar and fish health certificate from BKIPM Class I Denpasar, then sharks was brought to I Gusti Ngurah Rai International Airport for final check and ready to be exported to the destination country. During 2015-2016 there were 559 sharks from the species of Carcharhinus melanopterus, Triaenodon obesus, Orectolobus maculatus, Atelomycterus marmoratus, Chiloscyllium plagiosum and Halaelurus maculosus that have been exported to the 12 destination countries. The EAFM analysis of lengths indicated that the shark's size was at a very young until adult age. Meanwhile, the EAFM analysis of ETP species shows there were 4 shark types of Near Threatened, 1 type of Least Concern status and 1 type of Not Evaluated. Finally the result of EAFM analysis on the effectiveness of shark trade license by BPSPL Denpasar showed that the decision was well executed and run effectively, and so far the shark fishery management at Bali Province is applied successfully.
\end{abstract}

Keywords: shark; Bali Province; export; EAFM

\begin{abstract}
Abstrak
Penelitian ini bertujuan untuk mengetahui alur perdagangan hiu sebagai komoditas ikan hias dari Provinsi Bali; data ekspor hiu dari Provinsi Bali selama tahun 2015-2016 dan hasil ukuran panjang hiu; hiu yang diekspor dalam kategori ETP spesies; serta efektivitas Pemberian Surat Rekomendasi Hiu dari BPSPL Denpasar berdasarkan analisis EAFM. Penelitian ini menggunakan metode eksplorasi dengan kuesioner, wawancara dan pengambilan data dari BPSPL Denpasar. Hasil penelitian menunjukkan bahwa alur perdagangan hiu dimulai dari hasil tangkapan nelayan yang dibeli oleh perusahaan eksportir ikan hiu, kemudian perusahaan tersebut harus mendapatkan surat rekomendasi peredaran hiu dari BPSPL Denpasar dan sertifikat kesehatan ikan dari BKIPM Kelas I Denpasar, selanjutnya hiu dan dokumen surat dibawa ke Bandar Udara Internasional I Gusti Ngurah Rai untuk dilakukan pengecekan terakhir dan hiu siap diekspor ke negara tujuan. Selama tahun 2015-2016 terdapat 559 ekor hiu yang terdiri dari spesies Carcharhinus melanopterus, Triaenodon obesus, Orectolobus maculatus, Atelomycterus marmoratus, Chiloscyllium plagiosum dan Halaelurus maculosus telah diekspor ke 12 negara tujuan. Hasil analisis EAFM menunjukkan bahwa ukuran hiu yang diekspor selama tahun 2015-2016 berada pada usia yang sangat muda-dewasa. Hasil analisis EAFM menunjukkan bahwa dari 6 jenis hiu yang diekspor, terdapat 4 jenis hiu berstatus hampir terancam (NT), 1 jenis berstatus belum mengkhawatirkan (LC) dan 1 jenis berstatus belum di evaluasi (NE). Selanjutnya, hasil analisis EAFM mengenai efektivitas Pemberian Surat Rekomendasi Hiu dari BPSPL Denpasar menunjukkan bahwa keputusan tersebut telah dijalankan dengan baik dan efektif, sehingga sejauh ini pengelolaan perikanan hiu di Provinsi Bali dapat dianggap berhasil.
\end{abstract}

Kata Kunci: hiu; Provinsi Bali; ekspor; EAFM 


\section{Pendahuluan}

Perairan Indonesia memiliki keanekaragaman sumberdaya perikanan yang tinggi, salah satunya adalah hiu (Sembiring et al., 2015). Bagian tubuh hiu yang memiliki nilai jual tinggi adalah sirip, yang umumnya dipasarkan secara lokal dan diekspor ke berbagai negara (Dit. KKJI-KKP, 2015). Selain sirip hiu, terdapat juga perdagangan hiu sebagai komoditas ikan hias. Data Balai Pengelolaan Sumberdaya Pesisir dan Laut (BPSPL) Denpasar menyebutkan bahwa selama bulan Januari-April tahun 2016, terdapat 541 ekor hiu yang diekspor oleh perusahaan eksportir ikan hiu dari wilayah Bali dan Jawa Timur melalui Bandar Udara Internasional I Gusti Ngurah Rai (Bali). Hiu yang diekspor tersebut terdiri dari hiu karang sirip hitam (Carcharhinus melanopterus) sebanyak 455 ekor dan hiu karang sirip putih (Triaenodon obesus) sebanyak 86 ekor. Permintaan ekspor hiu tersebut berasal dari 16 negara yang didominasi dari Hong Kong sebanyak 358 ekor (Nurcahyo, 2016).

Permintaan pasar internasional yang tinggi terhadap hiu sebagai komoditas ikan hias menjadi salah satu alasan perdagangan hiu terus berlangsung hingga saat ini dan menyebabkan kegiatan penangkapan hiu juga mengalami peningkatan (Yates et al., 2012). Hal ini dikhawatirkan akan mengancam populasi hiu di masa yang akan dating (Mourier et al., 2013). Tertangkapnya hiu yang berusia muda maupun dewasa, akan mengurangi kesempatan bagi hiu jantan dan betina untuk dapat bereproduksi. Akibatnya jumlah individu baru yang dihasilkan tidak cukup untuk mempertahankan populasi hiu di alam (Graham and Daley, 2011). Sementara itu, di sisi lain sumberdaya perikanan hiu menjadi salah satu penghasilan utama yang telah memberikan kesejahteraan bagi nelayan penangkap, pengepul, penjual dan eksportir yang menjadikan hiu sebagai target perikanan mereka (BPSPL Denpasar, 2015).

Penelitian mengenai kegiatan dan alur perdagangan hiu sebagai komoditas ikan hias dari Provinsi Bali sejauh ini belum banyak dilakukan. Oleh karena itu, penelitian ini dilaksanakan untuk memperoleh data dan informasi awal mengenai alur perdagangan hiu sebagai komoditas ikan hias dari Provinsi Bali. Hasil dari penelitian ini diharapkan dapat memberikan gambaran data dan informasi yang dibutuhkan bagi pemerintah di tingkat daerah, Provinsi Bali, Kementerian Kelautan dan Perikanan maupun pemangku kepentingan lain sebagai bahan pertimbangan dalam mengevaluasi kegiatan perdagangan hiu dan menentukan kebijakan pengelolaan sumberdaya perikanan hiu secara berkelanjutan, sehingga dapat memberikan manfaat bagi kesejahteraan masyarakat pada saat ini maupun yang akan datang.

\section{Metode Penelitian}

Penelitian ini menggunakan metode kuesioner, wawancara dan pengambilan data dari BPSPL Denpasar selama tahun 2015-2016. Informasi mengenai alur perdagangan hiu sebagai komoditas ikan hias dari Provinsi Bali didapatkan dengan menyebarkan kuesioner penelitian kepada 5 perusahaan eksportir ikan hiu yang berada di Provinsi Bali (CV. Cahaya Baru, PT. Diyo Enggal Makmur, PT. Bali Double C, PT. Tanjung Sari Aquarium dan CV. Sarana Teknik), sedangkan informasi mengenai efektivitas pemberian Surat Rekomendasi Peredaran Hiu oleh BPSPL Denpasar didapatkan dari hasil wawancara dengan Kepala Seksi Program dan Evaluasi BPSPL Denpasar. Data jumlah ekspor hiu, jenis-jenis hiu yang diekspor dan negara tujuan perdagangan ekspor hiu dari Provinsi Bali selama tahun 2015-2016 diperoleh dari BPSPL Denpasar. Penelitian dilaksanakan pada tanggal 1 Januari-28 Februari 2017.

Analisis data dilakukan berdasarkan prinsip EAFM (Ecosystem Approach to Fisheries Management), yaitu sebuah konsep yang menyeimbangkan pemanfaatan sumberdaya perikanan untuk kepentingan sosial ekonomi masyarakat dengan tetap mempertimbangkan ketersediaan sumberdaya perikanan dan ekosistemnya melalui sebuah pengelolaan perikanan yang terpadu (Dit. SDI-KKP, 2013). Adapun analisis data dalam EAFM yang digunakan yaitu ukuran ikan, Endangered species, Threatened species, dan Protected species (ETP) serta mekanisme pengambilan keputusan. Data yang dihasilkan kemudian dijelaskan secara deskriptif dalam bentuk gambar maupun tabel.

\section{Hasil}

\subsection{Jenis Hiu yang dicari Perusahaan Eksportir}

Jenis-jenis hiu yang dicari oleh perusahaan eksportir ikan hiu untuk diekspor ke luar negeri terdiri dari 4 jenis, yaitu hiu karang sirip hitam (Carcharhinus melanopterus), hiu karang sirip putih (Triaenodon obesus), hiu mungsing atau hiu tokek 
Tabel 1

Jenis-Jenis Ikan hiu yang dicari oleh Perusahaan

\begin{tabular}{|c|c|c|c|c|}
\hline No. & Nama Lokal & Nama Umum & $\begin{array}{l}\text { Ukuran } \\
(\mathrm{cm})\end{array}$ & Nelayan \\
\hline 1. & Hiu Karang Sirip Hitam & Black Tip Reef Shark (Carcharhinus melanopterus) & $30-80$ & $\begin{array}{l}\text { Banyuwangi, } \\
\text { Jimbaran, Serangan }\end{array}$ \\
\hline 2. & Hiu Karang Sirip Putih & White Tip Reef Shark (Triaenodon obesus) & $30-100$ & $\begin{array}{l}\text { Banyuwangi, } \\
\text { Jimbaran, Serangan }\end{array}$ \\
\hline 3. & $\begin{array}{l}\text { Hiu Mungsing, Hiu } \\
\text { Tokek }\end{array}$ & $\begin{array}{l}\text { Coral Catshark } \\
\text { (Atelomycterus marmoratus) }\end{array}$ & $25-35$ & $\begin{array}{l}\text { Banyuwangi, } \\
\text { Serangan }\end{array}$ \\
\hline 4. & Hiu Zebra & Whitespotted Bamboo Shark (Chiloscyllium plagiosum) & $30-35$ & $\begin{array}{l}\text { Banyuwangi, } \\
\text { Serangan }\end{array}$ \\
\hline
\end{tabular}

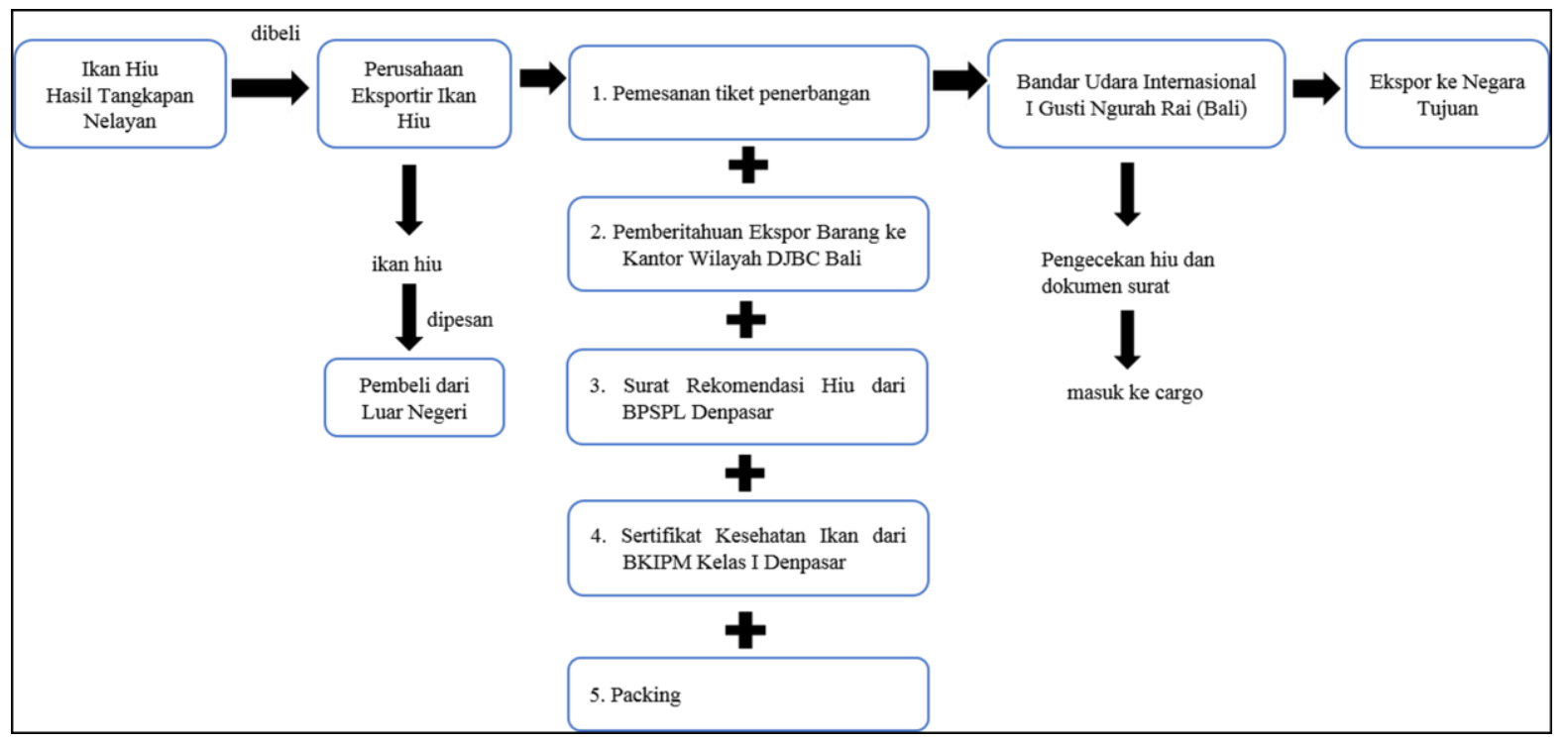

Gambar 1. Bagan Alur Perdagangan Hiu sebagai Komoditas Ikan Hias dari Provinsi Bali

(Atelomycterus marmoratus), dan hiu zebra (Chiloscyllium plagiosum). Hiu karang sirip hitam (Carcharhinus melanopterus) merupakan jenis hiu yang paling sering dicari oleh perusahaan eksportir ikan hiu karena permintaan ekspor terhadap hiu tersebut sangat tinggi. Lokasi nelayan yang menangkap ikan hiu antara lain Serangan (Bali), Jimbaran (Bali) dan Banyuwangi (Jawa) (Tabel 1).

\subsection{Alur Perdagangan Hiu sebagai Komoditas Ikan Hias dari Provinsi Bali}

Alur perdagangan hiu sebagai komoditas ikan hias dari Provinsi Bali dimulai dari hiu hasil tangkapan nelayan yang dibeli oleh perusahaan eksportir ikan hiu dalam keadaan masih hidup, sehat dan tidak cacat. Selanjutnya hiu yang dibeli dari nelayan tersebut akan ditempatkan dalam akuarium pemeliharaan dan dipelihara hingga siap diekspor. Kemudian apabila terdapat terdapat permintaan ekspor hiu dari luar negeri, maka perusahaan eksportir ikan hiu harus melakukan proses pemesanan tiket penerbangan, mengajukan dokumen Pemberitahuan Ekspor Barang (PEB) ke Kantor Wilayah Direktorat Jenderal Bea dan Cukai (Kantor Wilayah DJBC) Bali, mengajukan surat rekomendasi peredaran hiu ke Balai Pengelolaan Sumberdaya Pesisir dan Laut (BPSPL) Denpasar, mengajukan sertifikat kesehatan ikan ke Balai Karantina Ikan, Pengendalian Mutu dan Keamanan Hasil Perikanan (BKIPM) Kelas I Denpasar serta melakukan proses pengepakan barang (packing). Selanjutnya hiu yang sudah di packing dalam styrofoam box beserta dokumen surat-surat tersebut dibawa ke Bandara Ngurah Rai untuk dilakukan pengecekan terakhir dan hiu siap diekspor ke negara tujuan (Gambar 1).

3.3 Data Ekspor, Negara Tujuan Ekspor dan Jenis-Jenis Ikan Hiu yang dieskpor dari Provinsi Bali Selama Tahun 2015-2016

Pada tahun 2015 terdapat 79 ekor hiu yang diekspor dan selama tahun 2016 terdapat 480 ekor hiu yang diekspor, sehingga total hiu yang 


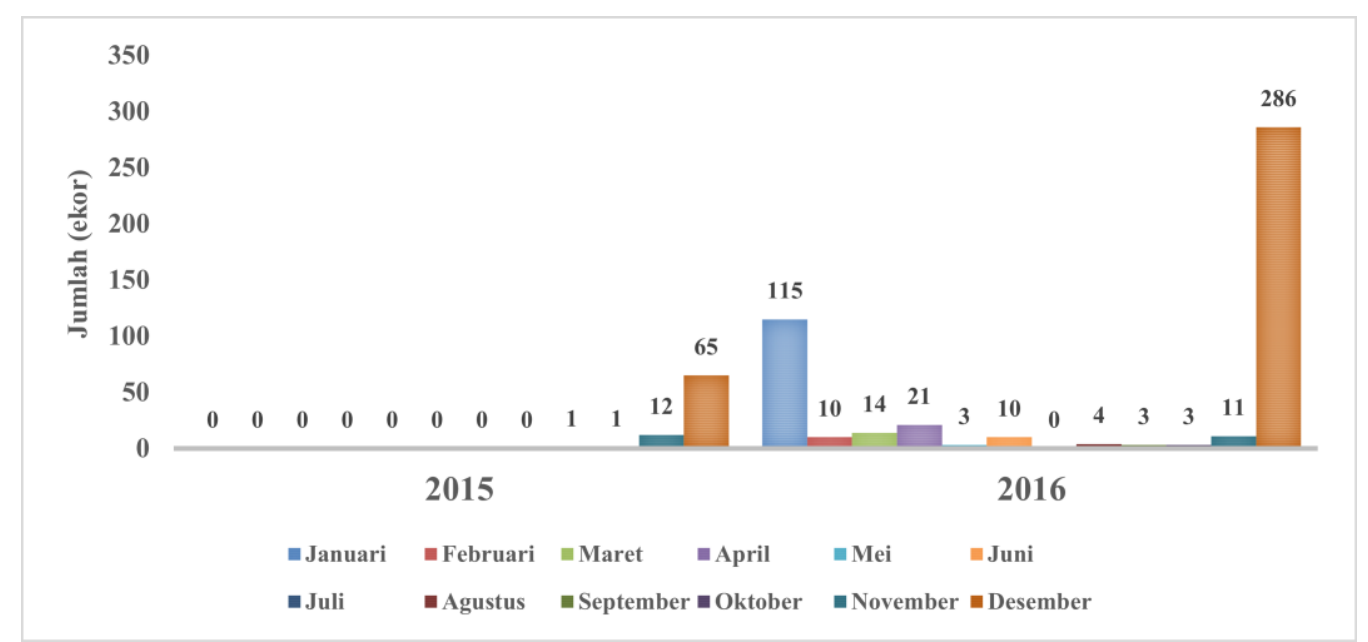

Gambar 2. Data Ekspor Ikan Hiu dari Provinsi Bali Selama Tahun 2015-2016

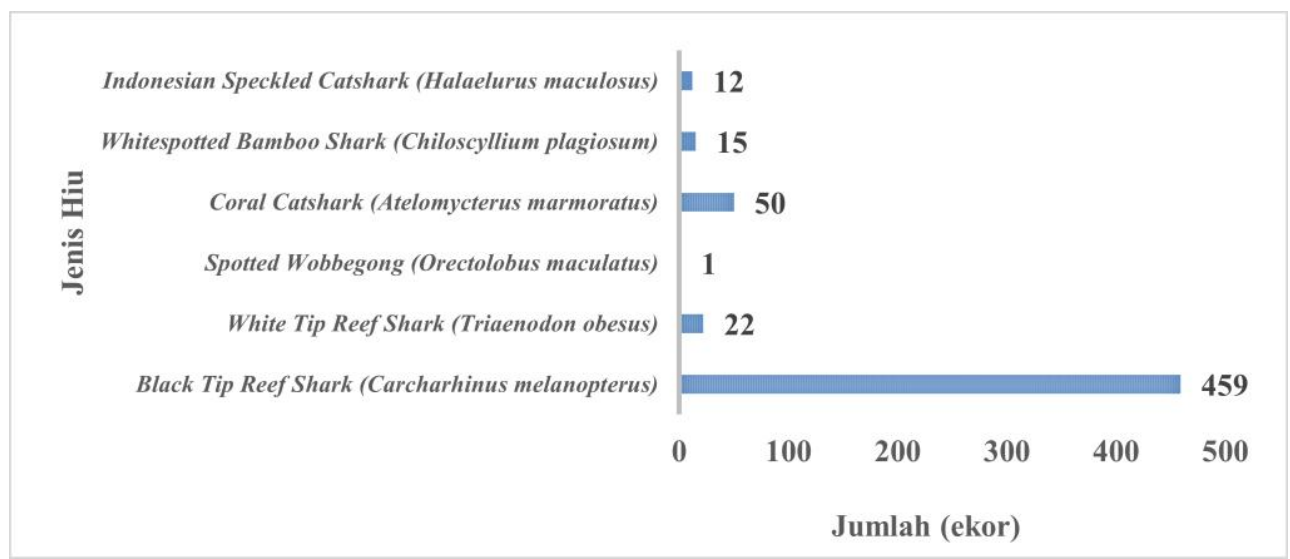

Gambar 3. Data Jenis-Jenis Ikan Hiu yang diekspor dari Provinsi Bali Selama Tahun 2015-2016

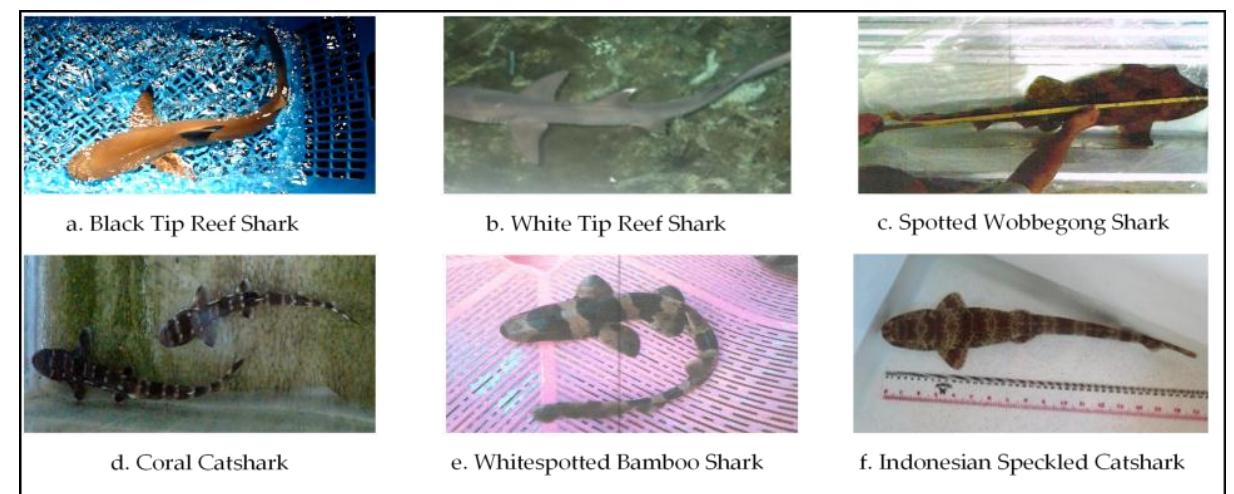

Gambar 4. Jenis-Jenis Ikan Hiu yang diekspor dari Provinsi Bali Selama Tahun 2015-2016

diekspor selama tahun 2015-2016 berdasarkan data BPSPL Denpasar adalah sebanyak 559 ekor (Gambar 2). Jenis hiu yang diekspor dari Provinsi Bali terdiri dari Black Tip Reef Shark (Carcharhinus melanopterus), White Tip Reef Shark (Triaenodon obesus), Spotted Wobbegong (Orectolobus maculatus), Coral Catshark (Atelomycterus marmoratus), Whitespotted Bamboo Shark (Chiloscyllium plagiosum) dan Indonesian Speckled Catshark (Halaelurus maculosus). Hiu Black Tip Reef Shark (Carcharhinus melanopterus) merupakan jenis hiu yang paling banyak diekspor selama tahun 2015-2016 yaitu sebanyak 459 ekor (Gambar 3). Jenis-jenis hiu yang diekspor tersebut dapat dilihat Gambar 3 dan Gambar 4.

Daerah tujuan ekspor hiu dari Provinsi Bali terdiri dari 12 negara, yaitu Kanada, Yunani, Jepang, Rusia, USA (New York dan Los Angeles), 


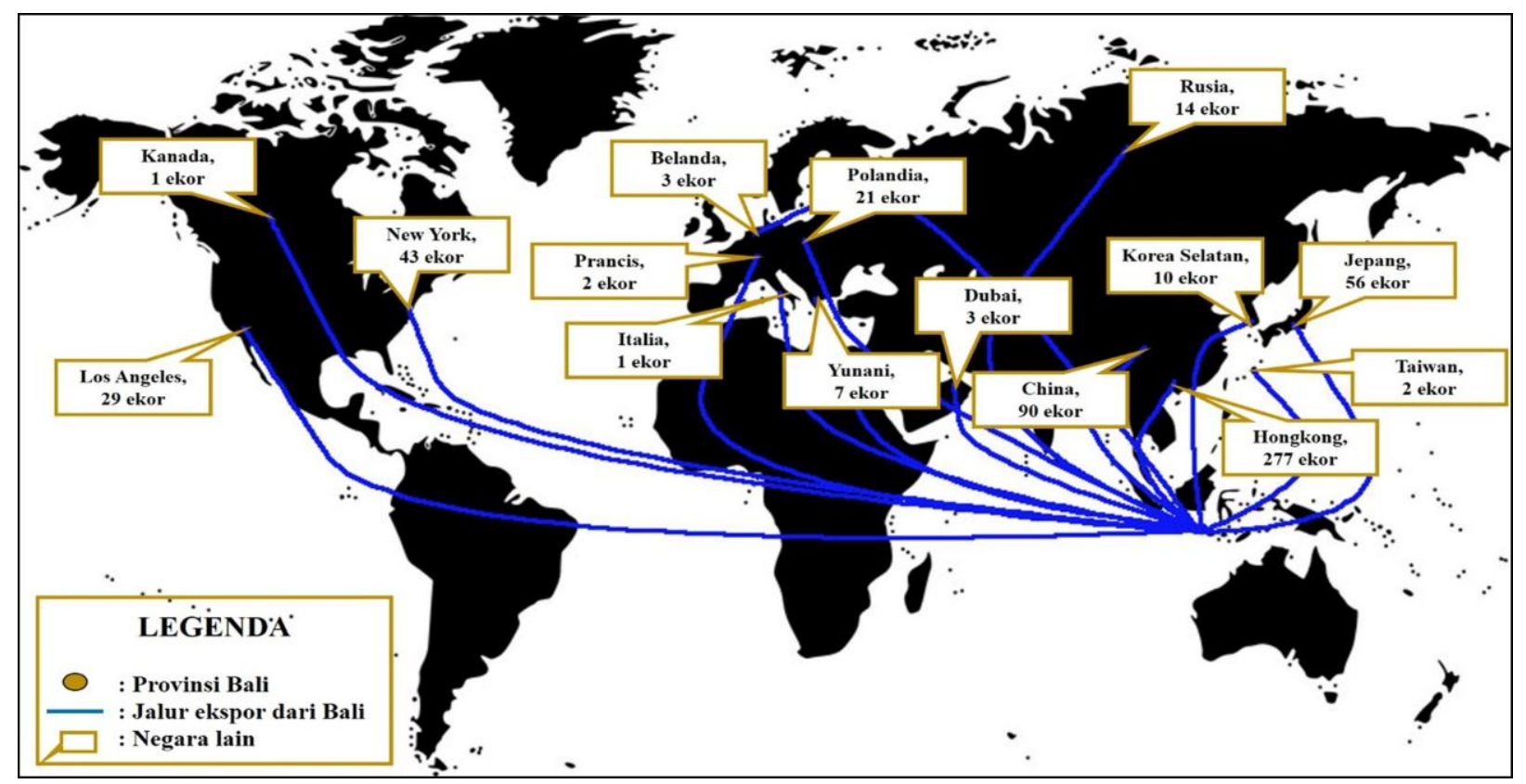

Gambar 5. Daerah Tujuan Ekspor Ikan Hiu dari Provinsi Bali Selama Tahun 2015-2016

Italia, Polandia, Korea Selatan, UEA (Dubai), Belanda, Prancis, dan RRC (China, Hong Kong dan Taiwan). Daerah yang menjadi tujuan ekspor ikan hiu didominasi oleh Hong Kong, dimana jumlah hiu yang diekspor ke negara tersebut adalah sebanyak 277 ekor (Gambar 5).

\subsection{Ukuran Ikan}

Ukuran panjang tubuh dapat dijadikan indikator untuk mengetahui tingkat kematangan seksual pada ikan. Menurut White et al. (2006), panjang tubuh hiu Black Tip Reef Shark (Carcharhinus melanopterus) dapat mencapai 140-180 cm; ukuran ketika lahir berkisar antara 48-50 cm; hiu jantan memasuki usia dewasa pada ukuran 98-113 cm dan betina pada ukuran $96-120 \mathrm{~cm}$. Ukuran hiu Black Tip Reef Shark (Carcharhinus melanopterus) yang diekspor dari Provinsi Bali selama 2015-2016 berkisar antara 30-90 cm, hal ini menunjukkan bahwa hiu tersebut merupakan ikan yang masih berusia sangat muda hingga hampir memasuki usia dewasa.

Panjang tubuh hiu White Tip Reef Shark (Triaenodon obesus) berkisar antara 60-200 cm; ukuran ketika lahir berkisar antara 52-60 cm; hiu jantan dan betina memasuki usia dewasa pada ukuran 105-120 cm (White et al., 2006). Ukuran hiu White Tip Reef Shark (Triaenodon obesus) yang diekspor dari Provinsi Bali selama 2015-2016 berkisar antara $60-100 \mathrm{~cm}$, hal ini menunjukkan bahwa hiu tersebut merupakan ikan yang masih berusia sangat muda hingga hampir memasuki usia dewasa.

Panjang tubuh hiu Spotted Wobbegong (Orectolobus maculatus) dapat mencapai $170 \mathrm{~cm}$; ukuran hiu ketika lahir sekitar $25 \mathrm{~cm}$; hiu jantan memasuki usia dewasa pada ukuran antara 85-88 $\mathrm{cm}$ dan hiu betina pada ukuran $94 \mathrm{~cm}$ (White et al., 2006). Ukuran panjang hiu Spotted Wobbegong (Orectolobus maculatus) yang diekspor dari Provinsi Bali selama 2015-2016 berukuran $100 \mathrm{~cm}$, hal ini menunjukkan bahwa hiu tersebut merupakan ikan yang sudah memasuki usia dewasa.

Panjang tubuh hiu Coral Catshark (Atelomycterus marmoratus) berkisar antara $25-70 \mathrm{~cm}$; hiu jantan memasuki usia dewasa pada ukuran $47 \mathrm{~cm}$ dan hiu betina pada ukuran $49 \mathrm{~cm}$ (White et al., 2006). Ukuran hiu Coral Catshark (Atelomycterus marmoratus) yang diekspor dari Provinsi Bali selama 2015-2016 berkisar antara 25-35 cm, hal ini menunjukkan bahwa hiu tersebut merupakan ikan yang masih berusia sangat muda.

Panjang tubuh hiu Whitespotted Bamboo Shark (Chiloscyllium plagiosum) berkisar antara 15-95 cm; ukuran ketika menetas berkisar antara 10-13 cm; hiu jantan memasuki usia dewasa pada ukuran antara 50-63 cm (White et al., 2006). Ukuran hiu Whitespotted Bamboo Shark (Chiloscyllium plagiosum) yang diekspor dari Provinsi Bali selama 2015-2016 berkisar antara 30-35 cm, hal ini menunjukkan bahwa hiu tersebut merupakan ikan yang masih berusia sangat muda. 
Panjang tubuh hiu Indonesian Speckled Catshark (Halaelurus maculosus) dapat mencapai $52 \mathrm{~cm}$; hiu jantan memasuki usia dewasa pada ukuran $40 \mathrm{~cm}$ (White et al., 2006). Ukuran hiu Indonesian Speckled Catshark (Halaelurus maculosus) yang diekspor dari Provinsi Bali selama 2015-2016 berkisar antara 44$49 \mathrm{~cm}$, hal ini menunjukkan bahwa hiu tersebut merupakan ikan yang sudah memasuki usia dewasa (Tabel 2).

\subsection{Endangered species, Threatened species, dan Protected species (ETP)}

Jenis-jenis ikan hiu yang diekspor dari Provinsi Bali selama tahun 2015-2016 berdasarkan data BPSPL Denpasar terdiri dari 6 jenis, dimana 4 jenis diantaranya (Black Tip Reef Shark (Carcharhinus melanopterus), White Tip Reef Shark (Triaenodon obesus), Coral Catshark (Atelomycterus marmoratus), dan Whitespotted Bamboo Shark (Chiloscyllium plagiosum)) berstatus hampir terancam (Near Threatened/NT), 1 jenis (Spotted Wobbegong (Orectolobus maculatus)) berstatus belum di evaluasi (Not Evaluated/NE) dan 1 jenis (Indonesian Speckled Catshark (Halaelurus maculosus)) berstatus belum mengkhawatirkan (Least Concern/LC) (Fahmi dan Dharmadi, 2013) (Tabel 3).

\subsection{Efektivitas SOP Pemberian Rekomendasi Hiu oleh BPSPL Denpasar}

SOP (Standar Operasional Prosedure) Nomor 20/KP3K.2/III/2015 tentang Pemberian Surat Rekomendasi Sirip Hiu Utuh bukan dilindungi, bukan dilarang keluar, dan bukan daftar appendiks CITES serta SOP Nomor 21/KP3K.2/III/2015 tentang Pemberian Surat Rekomendasi Sirip Hiu Produk Olahan bukan di lindungi, bukan dilarang keluar, dan bukan daftar appendiks CITES diterbitkan oleh Direktorat Konservasi Kawasan dan Jenis Ikan (Kementerian Kelautan dan Perikanan) pada tanggal 2 Maret 2015. Direktorat Konservasi Kawasan dan Jenis Ikan bersama dengan BPSPL Denpasar telah memberikan sosialisasi mengenai SOP tersebut kepada nelayan, pengusaha perikanan, penyuluh perikanan dan lembaga atau instansi pemerintah di Provinsi Bali, Lombok Timur dan Jawa Timur (Nurcahyo, 2015a; 2015b; 2015c).

Kasubdit Pemanfaatan Kawasan dan Jenis Ikan (Direktorat Konservasi Kawasan dan Jenis IkanKementerian Kelautan dan Perikanan) dalam sosialisasi tersebut menyampaikan bahwa saat ini setiap proses ekspor sirip hiu, sirip hiu produk olahan maupun hiu hidup dari wilayah Republik Indonesia ke luar negeri harus mematuhi SOP Pemberian Surat Rekomendasi Hiu nomor 20 dan 21 tahun 2015. Penerapan SOP tersebut bertujuan untuk menghindarkan terjadinya peredaran jenis hiu yang ditetapkan sebagai perlindungan penuh serta jenis hiu yang dilarang keluar dari wilayah Republik Indonesia sesuai dengan Peraturan Menteri Kelautan dan Perikanan Nomor 34 Tahun 2015 mengenai Larangan Pengeluaran Ikan Hiu Koboi (Carcharhinus longimanus) dan Hiu Martil (Sphyrna lewini, S. mokarran, S. zygaena) dari wilayah Negara Republik Indonesia (Nurcahyo, 2015b).

Nelayan, pengusaha perikanan dan lembaga atau instansi pemerintah yang diberikan sosialisasi tersebut mendukung kebijakan SOP Pemberian Surat Rekomendasi Hiu dan berharap agar semua pihak dapat melaksanakan kebijakan yang telah ditetapkan oleh pemerintah tersebut secara bersama-sama agar sumberdaya perikanan hiu tetap lestari, sehingga dapat memberikan manfaat bagi kesejahteraan masyarakat (Nurcahyo, 2015a; 2015b; 2015c).

Kepala BPSPL Denpasar (Bapak Suko Wardono, A.Pi., M.Si) menegaskan bahwa pemberian rekomendasi tersebut sangat efektif untuk menekan dan mengendalikan peredaran hiu, khususnya bagi produk hiu yang akan dikeluarkan dari wilayah Republik Indonesia. Data BPSPL Denpasar menyebutkan bahwa selama bulan Januari-April tahun 2016 terdapat 179,6 ton permohonan rekomendasi hiu dan pari (produk dan turunnya) yang diekspor oleh pengusaha perikanan dari wilayah Jawa Timur, hBali, Nusa Tenggara Barat (NTB) dan Nusa Tenggara Timur (NTT), namun dari permohonan tersebut hanya dikeluarkan rekomendasi sebanyak 39,5 ton karena diketahui sebagian dari produk yang akan dikirim tersebut terdapat jenis hiu yang dilarang dikeluarkan dari wilayah Republik Indonesia (Nurcahyo, 2016).

\section{Pembahasan}

Hiu Black Tip Reef Shark (Carcharhinus melanopterus) ditemukan pada hasil tangkapan nelayan yang didaratkan di Pelabuhan Perikanan Nusantara (PPN) Prigi, PPN Brondong, Pangkalan Pendaratan Ikan (PPI) Tanjung Luar, PPI Oeba dan Tempat Pelelangan Ikan (TPI) Bom Kalianda. 
Ukuran panjang hiu yang didaratkan berkisar antara 52-140 cm dan didominasi oleh jenis kelamin betina (BPSPL Denpasar, 2015; Parluhutan dan Imanjar, 2013). Hiu White Tip Reef Shark (Triaenodon obesus) ditemukan pada hasil tangkapan nelayan yang didaratkan di PPN Brondong, PPI Kedonganan, PPI Tanjung Luar dan PPI Oeba. Ukuran panjang hiu yang didaratkan berkisar antara 26-156 cm dan didominasi oleh jenis kelamin betina (BPSPL Denpasar, 2015).

Hiu Whitespotted Bamboo Shark (Chiloscyllium plagiosum) ditemukan pada hasil tangkapan nelayan yang didaratkan di PPN Prigi dan TPI Bom Kalianda. Ukuran panjang hiu yang didaratkan berkisar antara 28-57 cm dan didominasi oleh jenis kelamin jantan (BPSPL Denpasar, 2015; Parluhutan dan Imaniar, 2013). Hiu Coral Catshark (Atelomycterus marmoratus) ditemukan pada hasil tangkapan nelayan yang didaratkan di PPN Tanjung Luar dan TPI Bom Kalianda. Ukuran panjang hiu yang didaratkan berkisar antara 35-69 $\mathrm{cm}$ dan didominasi oleh jenis kelamin jantan (BPSPL Denpasar, 2015; Parluhutan dan Imaniar, 2013). Informasi mengenai sebaran hiu Spotted Wobbegong (Orectolobus maculatus) dan Indonesian Speckled Catshark (Halaelurus maculosus) di Indonesia tidak ditemukan.

Tingginya nilai ekonomi hiu merupakan salah satu dasar perdagangan hiu terus berlangsung hingga saat ini. Namun di lain pihak, aspek keberlanjutan sumberdaya belum menjadi perhatian dari pelaku usaha. Pengendalian jumlah perdagangan ekspor ikan hiu harus dilakukan di Indonesia sebelum kondisinya mencapai titik kritis yang beresiko terhadap menurunnya populasi hiu, mengingat banyaknya jumlah ikan hiu yang dieskpor dari Provinsi Bali selama tahun 2015-2016 yaitu sebesar 559 ekor. Dulvy et al. (2014) mengatakan bahwa sebagian besar populasi hiu di alam mengalami penurunan akibat oleh adanya kegiatan eksploitasi selama bertahun-tahun dan kegiatan perdagangan internasional. Mengingat fungsi penting hiu bagi stabilitas dan ekosistem laut, maka implementasi pemanfaatan dan manajemen sumberdaya perikanan hiu yang efektif dan berkelanjutan harus diterapkan secara serius agar populasi hiu tersebut tidak menjadi punah dalam rangka pemanfaatan secara lestari dan berkesinambungan untuk jangka panjang.

Pemerintah di tingkat daerah, Provinsi Bali, Kementerian Kelautan dan Perikanan maupun pemangku kepentingan lain diharapkan dapat mengevaluasi kegiatan perdagangan hiu kemudian menentukan suatu kebijakan pengelolaan sumberdaya perikanan hiu. Langkah awal untuk membuat kebijakan mengenai pengelolaan sumberdaya perikanan hiu dapat dimulai dengan mengumpulkan data mengenai jenis-jenis, ukuran dan jumlah hiu yang diekspor oleh perusahaan eksportir hiu di Indonesia, kemudian menentukan suatu kebijakan mengenai pembatasan jumlah perdagangan hiu dalam suatu periode waktu tertentu dan atau membuat kebijakan mengenai ukuran hiu yang

Tabel 2

Data Ukuran Hiu yang dieskpor Selama Tahun 2015-2016

\begin{tabular}{clc}
\hline No. & \multicolumn{1}{c}{ Jenis Hiu } & Ukuran $(\mathrm{cm})$ \\
\hline 1. & Black Tip Reef Shark (Carcharhinus melanopterus) & $30-90$ \\
2. & White Tip Reef Shark (Triaenodon obesus) & $60-100$ \\
3. & Spotted Wobbegong (Orectolobus maculatus) & 100 \\
4. & Coral Catshark (Atelomycterus marmoratus) & $25-35$ \\
5. & Whitespotted Bamboo Shark (Chiloscyllium plagiosum) & $30-35$ \\
6. & Indonesian Speckled Catshark (Halaelurus maculosus) & $44-49$ \\
\hline
\end{tabular}

Tabel 3

Jenis Hiu yang dieskpor Selama Tahun 2015-2016 beserta Status Konservasi IUCN Red List

\begin{tabular}{cll}
\hline No. & \multicolumn{1}{c}{ Jenis Hiu } & \multicolumn{1}{c}{ Status IUCN Red List } \\
\hline 1. & Black Tip Reef Shark (Carcharhinus melanopterus) & Hampir Terancam (Near Threatened/NT) \\
2. & White Tip Reef Shark (Triaenodon obesus) & Hampir Terancam (Near Threatened/NT) \\
3. & Spotted Wobbegong (Orectolobus maculatus) & Belum di Evaluasi (Not Evaluated/NE) \\
4. & Coral Catshark (Atelomycterus marmoratus) & Hampir Terancam (Near Threatened/NT) \\
5. & Whitespotted Bamboo Shark (Chiloscyllium plagiosum) & Hampir Terancam (Near Threatened/NT) \\
6. & Indonesian Speckled Catshark (Halaelurus maculosus) & Belum Mengkhawatirkan (Least Concern/LC) \\
\hline
\end{tabular}


diperbolehkan untuk diekspor serta memberikan sosialisasi mengenai jenis-jenis yang dilindungi di Indonesia, jenis-jenis hiu yang boleh dan tidak boleh diperdagangkan di Indonesia serta memberikan sosialisasi kepada masyarakat, nelayan dan pengusaha perikanan untuk tidak menangkap atau memperdagangkan hiu pada ukuran yang belum dewasa. Hal ini bertujuan agar sumberdaya perikanan hiu tetap lestari, sehingga dapat memberikan manfaat bagi kesejahteraan masyarakat pada saat ini maupun yang akan datang.

\section{Simpulan}

Alur perdagangan hiu sebagai komoditas ikan hias dari Provinsi Bali dimulai dari hiu hasil tangkapan nelayan yang dibeli oleh perusahaan eksportir ikan hiu, kemudian perusahaan eksportir ikan hiu tersebut harus melakukan proses pemesanan tiket penerbangan, mengajukan dokumen PEB ke Kantor Wilayah DJBC Bali, mengajukan surat rekomendasi peredaran hiu ke BPSPL Denpasar, mengajukan sertifikat kesehatan ikan ke BKIPM Kelas I Denpasar serta melakukan proses pengepakan barang (packing). Selanjutnya hiu yang sudah di packing beserta dokumen surat-surat tersebut dibawa ke Bandara Ngurah Rai untuk dilakukan pengecekan terakhir dan hiu siap diekspor ke negara tujuan. Data perdagangan ekspor hiu selama tahun 2015-2016 menunjukkan bahwa telah diekspor sebanyak 559 ekor hiu yang terdiri dari spesies Carcharhinus melanopterus, Triaenodon obesus, Orectolobus maculatus, Atelomycterus marmoratus, Chiloscyllium plagiosum dan Halaelurus maculosus ke 12 negara tujuan, yang didominasi oleh Hong Kong yaitu sebanyak 277 ekor.

\section{Ucapan terimakasih}

Ucapan terimakasih disampaikan kepada Kepala BPSPL Denpasar (Bapak Suko Wardono, A.Pi., M.Si), Kepala Seksi Program dan Evaluasi BPSPL Denpasar (Bapak Permana Yudiarso, ST., MT) beserta seluruh staff BPSPL Denpasar, serta Pimpinan beserta seluruh staff dan karyawan Perusahaan CV. Sarana Teknik, PT. Tanjung Sari Aquarium, PT. Diyo Enggal Makmur, PT. Bali Double $\mathrm{C}$ dan CV. Cahaya Baru yang telah bersedia membantu dan memberikan banyak informasi yang penulis perlukan selama kegiatan penelitian berlangsung.

\section{Daftar Pustaka}

BPSPL Denpasar. (2015). Profil Survei Monitoring Populasi Jenis Ikan Hiu di Jawa Timur, Bali, Nusa Tenggara Barat dan Nusa Tenggara Timur. Denpasar, Indonesia: Balai Pengelolaan Sumberdaya Pesisir dan Laut (BPSPL) Denpasar, Direktorat Jenderal Pengelolaan Ruang Laut, Kementerian Kelautan dan Perikanan Republik Indonesia.

Dit. SDI-KKP. (2013). Modul Penilaian Indikator untuk Pengelolaan Perikanan Berpendekatan Ekosistem (Ecosystem Approach and Fisheries Management). Bogor, Indonesia: Direktorat Sumberdaya Ikan, Direktorat Jenderal Perikanan Tangkap, Kementerian Kelautan dan Perikanan Republik Indonesia.

Dit. KKJI-KKP. (2015). Pedoman Identifikasi dan Pendataan Hiu Apendiks II CITES. Jakarta, Indonesia: Direktorat Konservasi Kawasan dan Jenis Ikan, Direktorat Jenderal Kelautan, Pesisir dan Pulau-Pulau Kecil, Kementerian Kelautan dan Perikanan Republik Indonesia.

Dulvy, N. K., Fowler, S.L., Musick, J.A., Cavanagh, R. D., Kyne, P. M., Harrison, L. R., Carlson, J. K., Davisdson, L. N. K., Fordham, S.V., Francis, M. P., Pollock, C. M., Simpfendorfer, C. A., Burgess, G. H., Carpenter, K. E., Compagno, L. V. J., Ebert, D. A., Gibson, C., Heupel, M. R., Livingstone, S. R., Sanciangco, J. C., Stevens, J. D., Valenti, S. and White, W. T. 2014. Extinction risk and conservation of the world's sharks and rays. eLIFE, 3, e00590.

Fahmi \& Dharmadi. (2013). Pengenalan Jenis-Jenis Hiu di Indonesia. Jakarta, Indonesia: Direktorat Konservasi Kawasan dan Jenis Ikan, Kementerian Kelautan dan Perikanan Republik Indonesia.

Graham, K. J., \& Daley, R. K. (2011). Distribution, reproduction and population structure of three gulper sharks (Centrophorus, Centrophoridae) in south-east Australian waters. Marine and Freshwater Research, 62(6), 583-595.

Mourier, J., Mills, S. C., \& Planes, S. (2013). Population structure, spatial distribution and life - history traits of blacktip reef sharks Carcharhinus melanopterus. Journal of fish biology, 82(3), 979-993.

Nurcahyo, H. (2015a). Pengusaha Perikanan di Bali Mendapatkan Sosialisasi SOP Pemberian Rekomendasi Sirip Hiu. [online] Balai Pengelolaan Sumberdaya Pesisir dan Laut (BPSPL) Denpasar, Direktorat Jenderal Pengelolaan Ruang Laut, Kementerian Kelautan dan Perikanan Republik Indonesia. (http://bpspldenpasar.info/pengusaha-perikanan-dibali-mendapatkan-sosialisasi-sop-pemberian-reko mendasi-sirip-hiu), [diakses: 14 Januari 2017].

Nurcahyo, H. (2015b). Nelayan dan Stakeholder di Lombok Timur Menerima Sosialisasi SOP Pemanfaatan Hiu. [online] Balai Pengelolaan Sumberdaya Pesisir dan Laut (BPSPL) Denpasar, Direktorat Jenderal 
Pengelolaan Ruang Laut, Kementerian Kelautan dan Perikanan Republik Indonesia. (http://bpspldenpasar. info/nelayan-dan-stakeholder-di-lombok-timurmenerima-sosialisasi-sop-pemanfaatan-hiu/), [diakses: 14 Januari 2017].

Nurcahyo, H. (2015c). Nelayan Lamongan Mendapatkan Sosialisasi SOP Hiu. [online] Balai Pengelolaan Sumberdaya Pesisir dan Laut (BPSPL) Denpasar, Direktorat Jenderal Pengelolaan Ruang Laut, Kementerian Kelautan dan Perikanan Republik Indonesia. (http://bpspldenpasar.info/nelayan-lamo ngan-mendapatkan-sosialisasi-sop-hiu/), [diakses: 14 Januari 2017].

Nurcahyo, H. (2016). Pemberian Rekomendasi Hiu Efektif untuk Menekan dan Mengendalikan Peredaran Hiu. [online] Balai Pengelolaan Sumberdaya Pesisir dan Laut (BPSPL) Denpasar, Direktorat Jenderal Pengelolaan Ruang Laut, Kementerian Kelautan dan Perikanan Republik Indonesia. (http://bpspldenpasar.kkp.go.id/pemberian-rekomen dasi-hiu-efektif-untuk-menekan-dan-mengendalikanperedaran-hiu), [diakses: 14 Januari 2017].
Parluhutan, D \& Imanjar, K. (2013). Keragaman Jenis Ikan Hiu yang didaratkan di TPI Bom Kalianda, Lampung Selatan. Loka Pengelolaan Sumberdaya Pesisir dan Laut Serang. Di dalam : Prosiding Simposium Hiu dan Pari di Indonesia. Pelaksanaan Prosiding Simposium Hiu dan Pari di Indonesia : IPB Convention Centre Bogor, 10 Juni 201, 15-21.

Sembiring, A., Pertiwi, N. P. D., Mahardini, A., Wulandari, R., Kurniasih, E. M., Kuncoro, A. W., Cahyani, N. K. D., Anggoro, A. W., Ulfa, M., Madduppa, H. H., Carpenter, K. E., Barber, P. H. \& Mahardika, G. N. (2015). DNA barcoding reveals targeted fisheries for endangered sharks in Indonesia. Fisheries Research, 164, 130-134.

White, W. T., Last, P. R., Stevens, J. D., Yearsley, G. K., Fahmi \& Dharmadi. (2006). Economically Important Shark and Rays of Indonesia. Lamb Print, Perth, Western Australia: Australian Centre for International Agricultural Research.

Yates, P. M., Heupel, M. R., Tobin, A. J., \& Simpfendorfer, C. A. (2012). Diversity in young shark habitats provides the potential for portfolio effects. Marine Ecology Progress Series, 458, 269-281.

(C) 2017 by the authors; licensee Udayana University, Indonesia. This article is an open access article distributed under the terms and conditions of the Creative Commons Attribution license (http://creativecommons.org/licenses/by/3.0/). 